\title{
AN ILLUSTRATED KEY TO THE IDENTIFICATION OF CENTIPEDES (CHILOPODA: SCOLOPENDROMORPHA) OF KERALA
}

\author{
P.M. Sureshan ${ }^{1}$, B.E. Yadav ${ }^{1}$ and C. Radhakrishnan ${ }^{2}$ \\ ${ }^{1}$ Western Regional Station, Zoological Survey of India, Pune, Maharashtra 411044, India. \\ ${ }^{2}$ Western Ghats Field Research Station, Zoological Survey of India, Kozhikode, Kerala 673002, India. \\ Email: ${ }^{1}$ zsipune@mah.nic.in; ${ }^{2}$ zsicalicut@sancharnet.in
}

\begin{abstract}
An illustrated key and the systematic list for the identificaiton of 15 species of scolopendrid centipedes under eight genera so far reported from Kerala is provided.
\end{abstract}

\section{Keywords}

Centipedes, Chilopida, India, Kerala, key, Scolopendridae, Scolopendromorpha, systematic list

\section{Introduction}

Centipedes are an economically important group of arthropods playing valuable role in the control of noxious insect pests in the terrestrial ecosystem (Yadav, 1994). They are often treated as creatures of nuisance value owing to their poisonous nature and painful bite, particularly of the members of the family Scolopendridae. The microhabitat of all the centipedes is the wet and moist places and they inhabit the environs below rotten barks, dry foliage, stones, heap of cowdung etc. Being a tropical megadiversity country, India is gifted with a rich variety of centipede fauna. A perusal of the recent literature on the Indian fauna reveals that systematic studies on centipedes have so far been restricted mainly to Deccan Plateau, Western Ghats, Indian Desert, Western Himalaya, U.P, Delhi, Rajastan, and Gujarat (Jangi \& Das, 1984; Yadav, 1993a,b,c; Khanna \& Yadav, 1997; Khanna, 2001). Khanna (2001) checklisted 100 species of centipedes belonging to 11 genera under two families from India.

In the present communication 15 species of Scolopendrid centipedes arranged in eight genera and two subfamilies pertaining to Kerala have been inventoried and an illustrated key is provided. Though not reported from Kerala, Scolopendra hardwickei Newport has also been included in the key owing to its recent reports from localities bordering the states of Kerala and Tamil Nadu (Rathinasabapathy \& Daniel, 1997; Rathinasabapathy \& Yadav, 2000) .

\section{Systematic list}

Class: Chilopoda

Sub class: Epimorpha

Order: Scolopendromorpha

Family: Scolopendridae

Subfamily: Scolopendrinae

Tribe: Scolopendrini

Arthrorhabdus jonesii Verhoeff, 1937

1937. Arthrorhabdus (Trachycormocephalus) jonesii, Verhoeff, Zool. Jahrb. (Syst.), 71: 384.

Cormocephalus nigrificatus Verhoeff, 1937

1937, Cormocephalus (Dehanonyx) nigrificatus, Verhoeff, 1937. Zool. Anz. Leipzig, 120: 81.

Scolopendra amazonica Bucherl, 1946

1946. Scolopendra morsitans amazonica, Bucherl, Mem. Inst. Butantan, 19: 135-137.

* Scolopendra hardwickei Newport, 1844

1844. Scolopendra hardwickei Newport, Ann. Nat. Hist., 13: 96.

Scolopendra morsitans Linn., 1758

1758. Scolopendra morsitans Linnaeus, Syst. Nat. Ed. 10: 638.

Scolopendra subspinipes dehaani Brandt, 1840

1840, Scolopendra subspinipes dehaani Brandt. Bull. Ac., St. Petersburg, 5: 152.

\section{Tribe Asanadini}

Asanada indica Jangi \& Dass, 1984

1984. Asanada indica, Jangi \& Dass, J. Scient. Indl. Res., 43(2): 38-39.

Asanada socotrana Pocock, 1899

1899. Asanada socotrana, Pocock, Bull. Liverpool Mus., 2: 9

Asanada sukhensis Jangi \& Dass, 1984

1984. Asanada indica, Jangi \& Dass, J. Scient. Indl. Res., 43(2): 38-39. 


\section{Subfamily: Otostigminae \\ Tribe: Otostigmini}

Otostigmus politus politus Karsch, 1881

1881, Otostigmus politum, Karsh, Berlin ent. Z., 25: 219.

Ethmostigmus platycephalus platycephalus (Newport, 1845) 1845, Heterostoma platycephalus platycephalus Newport, Trans Linn. Soc., 19: 415.

Digitipes gravelyi Jangi \& Dass, 1984

1984, Digitipes gravelyi Jangi \& Dass, J. Scient. Indl. Res., 43(2): 41.

Digitipes chhotanii Jangi \& Dass, 1984

1984, Digitipes chhotanii, Jangi \& Dass. J. Scient. Indl. Res., 43(2): 46.

Digitipes indicus Jangi \& Dass, 1984

1984, Digitipes indicus, Jangi \& Dass. J. Scient. Indl. Res., 43(2): 46-47.

Rhysida nuda subnuda Jangi, 1955

1955. Rhysida nuda subnuda Jangi, Ann. Mag. Nat. Hist., Ser.12, 8: 69-80.

* Not so far reported from Kerala; reported from localities bordering Kerala and Tamil Nadu, included persuming possible occurrence in Kerala.

\section{Discussion}

Topography, bioclimate and two monsoon seasons in Kerala provide optimal niches for centipedes. The centipedes form an important faunal element in the soils of Kerala. The present study deals with 15 species of Scolopendrid centipedes under eight genera pertaining to Kerala. Among the members of the subfamily Scolopendrinae, species from the genera Scolopendra Linn., Cormocephalus Newport, Asanada Meinet and Arthrorhabdus Pocock are reported. Scolopendra amazonica Bucherl and Scolopendra morsitans Linn. are cosmopolitan sympatric species of which the former is most dominant. The genus Arthrorhabdus is a rare genus in Asia and is represented in Kerala by the endemic species, A. jonesii Verhoff. The genus is known by only five species at global level.

Though Cormocephalus is a common genus in India, with eight species, it is represented by a single species $C$. nigrificatus from Kerala. Tribe Asanadini of Scolopendrinae containing smaller and slender centipedes that generally inhabit termite mounts is fairly represented in Kerala. In the subfamily Otostigminae having species with rounded spiracles, members of the genera Otostigmus Porat, Digitipes Attems, Rhysida Wood and Ethmostigmus Pocock are reported from Kerala, of which the former two have 9 pairs and the remaining with 10 pairs of oval spiracles. The genus Digitipes is fairly well known and Otostigmus is of rare occurrence in Kerala. The members of the gneus Ethmostigmus though can be collected in the rainy season, is of rare occurrence (Yadav, 1993b).

\section{Acknowledgements}

The authors are grateful to Dr. J.R.B. Alfred, Director, Zoological Survey of India, Kolkata; to the Officer-in-charge, Zoological Survey of India, Western Regional Station, Pune for providing facilities; to Dr.Vinod Khanna, Northern Regional Station, Zoological Survey of India, Dehradun, for critically going through the manuscript and offering useful suggestions; also due to Sri. P.W. Garde, Senior Artist, ZSI, WRS, Pune for the drawings.

\section{References}

Jangi, B.S. and C.M.S. Dass (1984). Scolopendridae of the Deccan. Journal of Scientific and Industrial Research 43: 27-54.

Khanna,V. (2001). A checklist of the Indian species of the centipedes (Chilopoda: Scolopendromorpha). Annals of Forestry 9(2): 199-219. Khanna, V. and B.E. Yadav (1997). Indian species of the centipede genus Scolopendra with key to their identification (Chilopoda: Scolopendridae). Records of the Zoological Survey of India 96(1-4). 211-220.

Rathinasabapathy, B. and B.A. Daniel (1997). Note on tiger centipede (Scolopendra hardwickei (Newport) from Coimbatore Zoological Park site, Anaikatty, Western Ghats. Zoos' Print 12(8): 1. Rathinasabapathy, B. and B.E. Yadav (2000). Centiptedes (Scolopendridae) of Coimbatore Zoological park Area, Anaikaty, Western Ghats. Zoos' Print 15(19): 327-328.

Yadav, B.E. (1993a). On a collection of centipedes (Myriapoda: Chilopoda) from Pune, Maharashtra. Records of the Zoological Survey of India 93(1-2): 165-174.

Yadav, B.E. (1993b). A report on some species of the genera Digitipes and Ethmostigmus (Chilopoda: Scolopendromorpha: Otostigmini) from Maharashtra. Records of the Zoological Survey of India. 93(34): 313-315.

Yadav, B.E. (1993c). Scolopendridae (Chilopoda) of Western Ghats with some first records from the state of Maharashtra. Records of the Zoological Survey of India 93(3-4): 321-328.

Yadav, B.E. (1994). The Scolopendrid centipedes. Science and Culture 60(6-12): 77-79. 


\section{Identification key}

1. Four ocelli on each side of head below antennae (Figs. 1, 13, 15) . . Family Scolopendridae ........2

1A. No ocelli, blind centipedes . . . . . . . . . . . . Family Cryptopidae (not reported from Kerala)

2. Spiracles triangular, longish, parallel to the long axis of the body (Fig. 2) ..... Subfamily Scolopendrinae

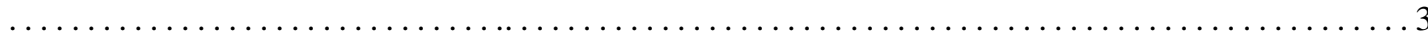

2A. Spiracles oval or round (Figs. 9, 10). Subfamily Otostigminae (single tribe Otostigmini) $\ldots \ldots \ldots \ldots 11$

3. Terminal leg segment with coxopleural process and pores (Figs.4, 14, 18) (Tribe Scolopendrini)......4

3A. Terminal leg segment without coxopleural process and pores (Fig. 23) (Tribe: Asanadini: Single genus Asanada Meinert: antennae extraordinarily short, not reaching backwards beyond the first segment of

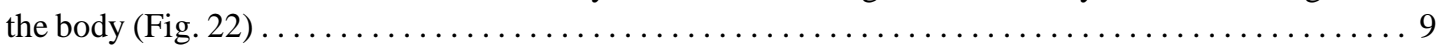

4. All legs without tarsal spurs (Fig. 8); cephalic plate bears 2 incomplete paramedian longitudinal sutures

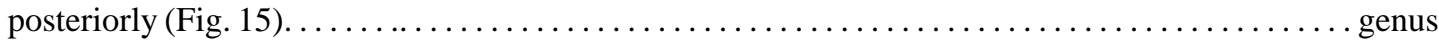
Cormocephalus Newport (Single species reported from Kerala: C. nigrificatus Verhoeff: 21st tergite without a longitudinal sulcus; lateral margination absent on tergites anterior to 21(Fig. 16); maxillepedes without prefemoral process)

4A. Legs mostly with tarsal spur (Fig. 3); cephalic plate without longitudinal sutures (Fig. 1)........5

5. $\quad 1^{\text {st }}$ tergite anteriorly overlaid by cephalic plate (Fig. 1); a pair of spinules at the base of the claws of last leg (Fig. 5); colour green or yellow usually with a darker cross bar on each body segment or body deep black; the legs bright orange, large and robust centipedes: genus Scolopendra Linnaeus . . . . . . . 6

5A. 1st tergite opposed to or overlaying cephalic plate; no spinules at the base of the claws of last legs; colour dull red with a blue or purplish tinge; small to moderate sized centipedes . ............genus Arthrorhabdus Pockock (rare in Asia: only one species A. jonesii Verhoff: Cephalic plate without basal plate; antennae with 17 articles, three basal glabrous and rest pilose; maxillipede dental plate with four teeth each; coxopleural process conical and tipped with two spines; first four legs with two tarsal spurs, remaining with one; anal leg prefemur with 1-2 spines ventro medially and three ventrally; 21 st tergite without median suture)

6. Anal leg prefemur ventrally with nine spines arranged in three rows of three each (Fig. 4) ....... 7

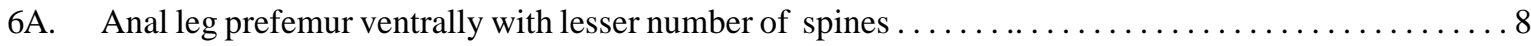

7. $20^{\text {th }}$ pair of walking legs without tarsal spur (Fig.6) .............. Scolopendra amazonica Bucherl

7A. $20^{\text {th }}$ pair of walking legs with tarsal spur (Fig. 3) .............. Scolopendra morsitans Linnaeus

8. Alternate dark green and brownish yellow tergal segments giving remarkably a banded apperarance to the trunk; anal leg prefemur without spines ventrally (Fig. 7). . . . . . . Scolopendra hadwickei Newport

8A. No such colour pattern on tergites; anal leg prefemur with spines ventrally $\ldots \ldots \ldots \ldots \ldots \ldots \ldots \ldots \ldots \ldots \ldots \ldots \ldots \ldots \ldots \ldots \ldots \ldots$ Scolopendra subspinipes dehani Brandt

9. Longitudinal median groove present on posterior half of anal leg prefemur and femur (Fig. 24) ........

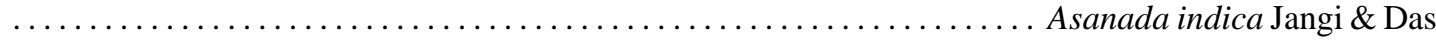

9A. Longitudinal median groove present on anal leg femur only (Fig. 23) ...................................10

10. Longitudinal median groove present throughout on anal leg femur ....... Asanada sokotrana (Pocock)

10A. Longitudinal median groove confined to posterior half of anal leg femur only (Fig. 25) ............

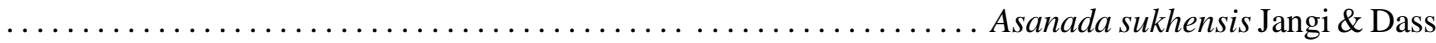

11. Nine pairs of spiracles, one each on leg bearing segments $3,5,8,10,12,14,16,18$ and $20 \ldots \ldots 12$ 
11A. 10 pairs of spiracles,one each on leg bearing segments $3,5,7,8,10,12,14,16,18$ and $20 \ldots \ldots 15$

12. Claw of second maxillae without spur (Fig. 26); femur of anal leg in male with a posteriomedial process

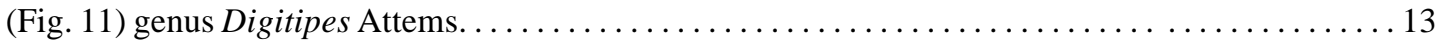

12A. Claw of second maxillae with a spur (Fig. 27); femur of anal leg in male without such a process. genus Otostigmus Porat (single species reported from Kerala: Otostigmus politus politus Karsh: first 5-6 legs with two tarsal spines and following legs up to $19^{\text {th }}$ with a single tarsal spur; tergites smooth)

13. 20th leg without tarsal spur, coxopleural process tipped with four spines and bearing two lateral spines

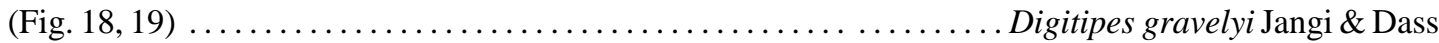

13A. 20th leg with a single tarsal spur; coxopleural process tipped with two spines and no lateral spines. . . 14

14. Lateral tergital margination beginning on seventh segment; posterior margin of 21 st sternite straight; first tarsus of anal leg nearly twice as long as second and second tarsus 3.5 times as long as claw (Fig. 21); prefemoral spines of anal leg comprising three ventro lateral and two ventro medial spines besides a dorso medial one; posteromedial femoral process of male short and stumpy . ........... $\ldots \ldots \ldots \ldots \ldots \ldots \ldots \ldots \ldots \ldots \ldots \ldots \ldots \ldots \ldots \ldots \ldots \ldots \ldots \ldots \ldots \ldots \ldots \ldots \ldots \ldots$ Ditipes chhotanii Jangi \& Dass

14A. Lateral tergital margination beginning on 11th leg bearing segment; posterior margin of 21 st sternite concave; first tarsus of anal leg 1.5 times as long as second and second tarsus slightly more than twice as long as claw (Fig. 20); prefemoral spines of anal leg comprising a ventro lateral and ventro medial spine

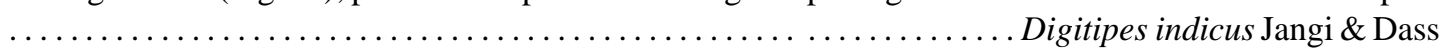

15. Prefemur of maxillepede with a medial dental process; first pair of spiracles not very large sieve like (Figs.

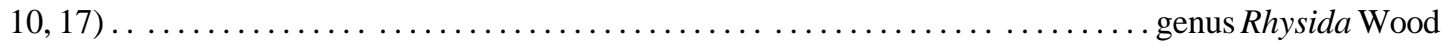
(only one species reported from Kerala: R.nuda subnuda Jangi: Tergites preceding 21st leg bearing segment ordinarily not marginate laterally and if at all hardly a couple of them involved and that too incompletely and weakly; 20th pair of legs bear tarsal spur (Fig. 14)

15A. Prefemur of maxillipede without a median dental proces; first pair of spiracles large and sieve like (Figs. $10,17) \ldots \ldots \ldots \ldots \ldots \ldots \ldots \ldots \ldots \ldots \ldots \ldots \ldots \ldots \ldots \ldots \ldots \ldots \ldots \ldots \ldots \ldots \ldots \ldots \ldots \ldots$ genus Ethmostigmus Poco.k (only one species reported from Kerala: E. platycephalus platycephalus (Newport): median dental plate of maxillepede with three teeth (Fig. 17); four basal antennal segments glabrous; posterior medial spiny process of anal leg prefemur curved and of normal size; anal leg prefemur with three ventro lateral spines; coxopleural process tipped with two to four spines and bearing dorsally $0-1$ spine) 


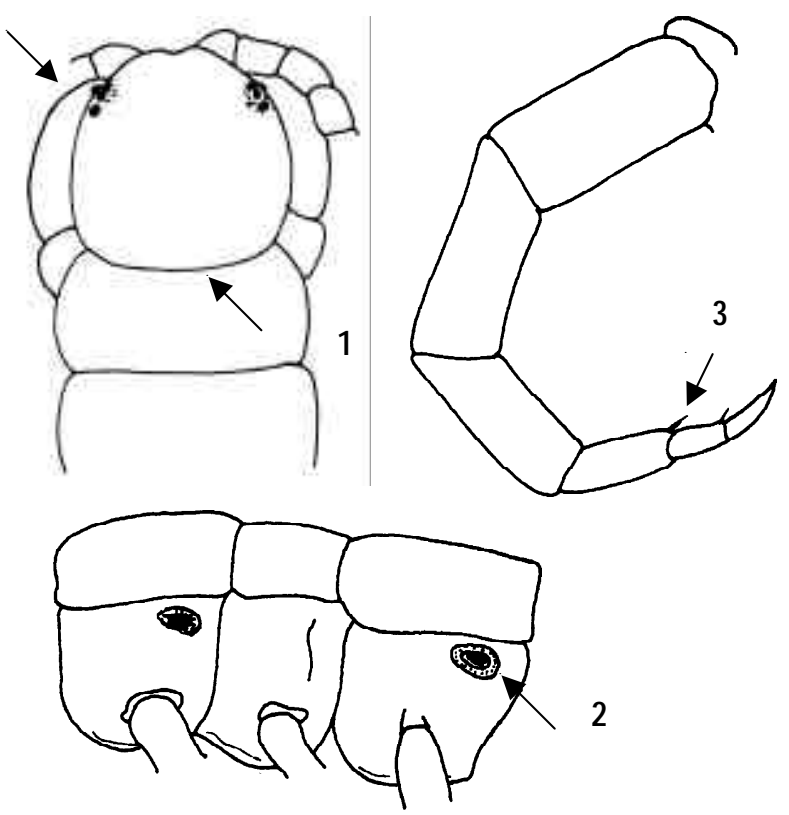

Figures 1-3. Scolopendra morsitans

1 - cephalic end in dorsal view; 2 - body segments in lateral view showing triangular spiracles; 3 - $20^{\text {th }}$ leg.

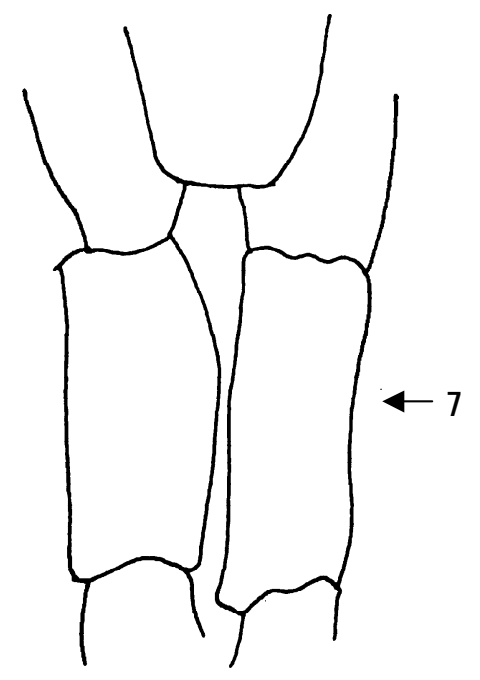

Figure 7. Scolopendra hardwickei

Caudal end (part) in ventral view showing anal leg prefemur

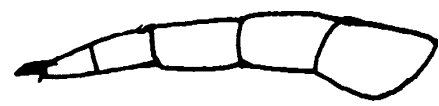

Figure 8. Cormocephalus nigrificatus

Leg

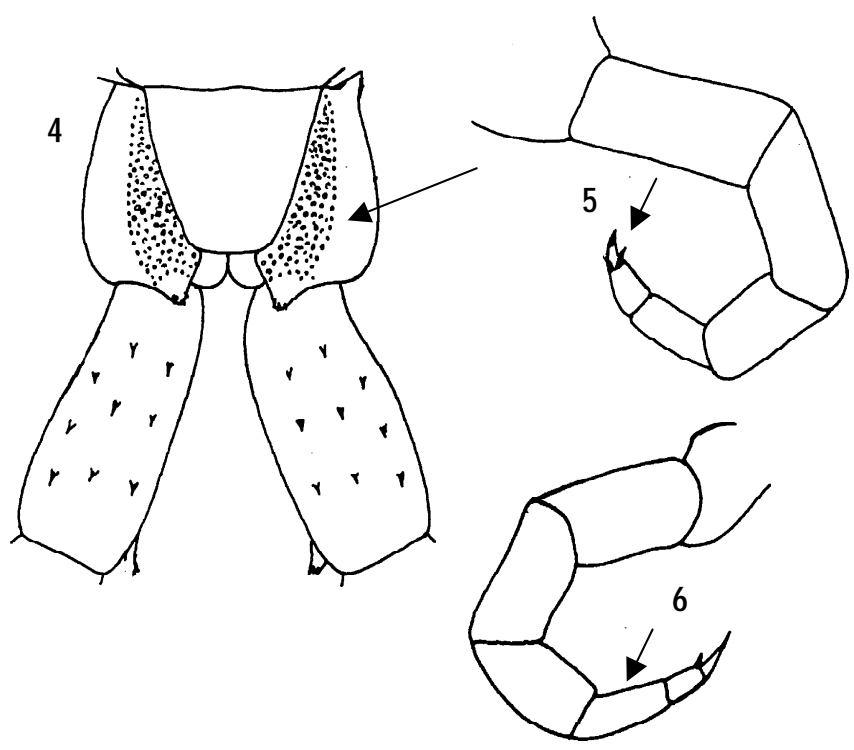

Figures 4-6. Scolopendra amazonica 4 - Cuadal end in ventral view showing $21^{\text {st }}$ sternite, coxopleural process and anal leg prefemur; 5 - anal leg; $6-20^{\text {th }}$ leg
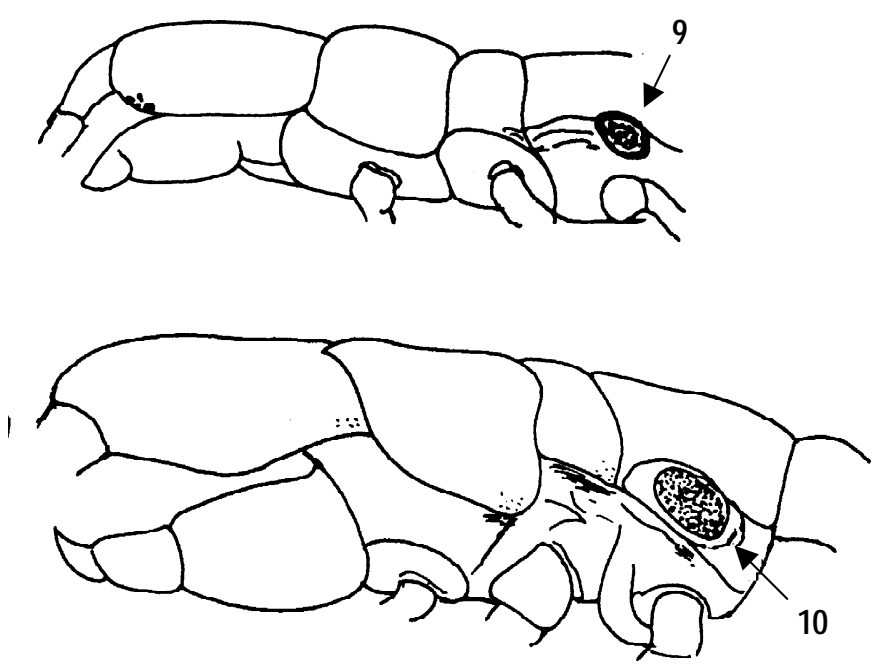

Figures 9-10. Anterior part of body segments in lateral view showing oval spiracles

9 - Rhysida nuda subnuda; 10 - Ethmostigmus platycephalus platycephalus 


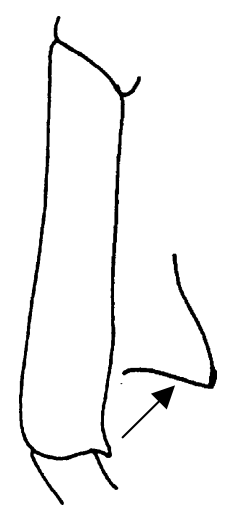

Figure 11. Digitipes sp. Anal leg femur of male
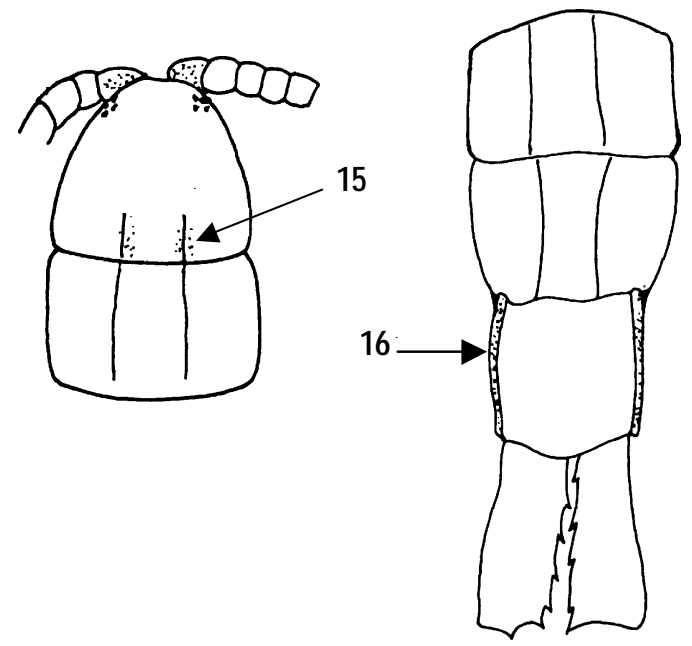

Figures 15-16. Cormocephalus nigrificatus

15 - Cephalic end in dorsal view; 16 - caudal end in drosal view showing last tergites and anal leg prefemur
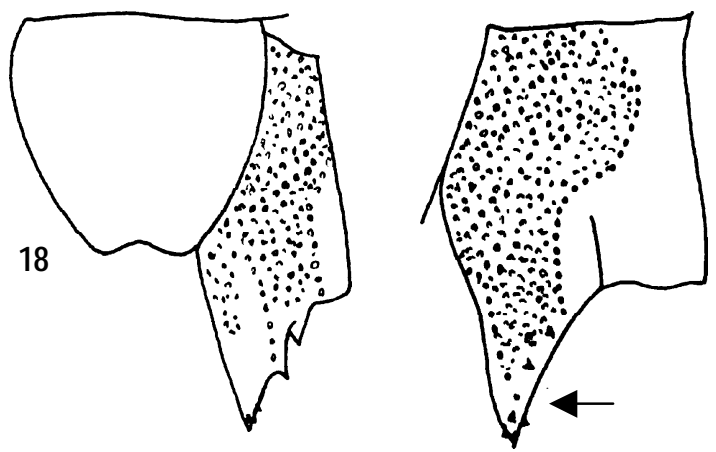

19

Figures 18-19. Digitipes gravelyi

18 - Part of caudal end in ventral view showing $21^{\text {st }}$ sternite and left coxopleuron; 19 - left coxopleuron in lateral view;
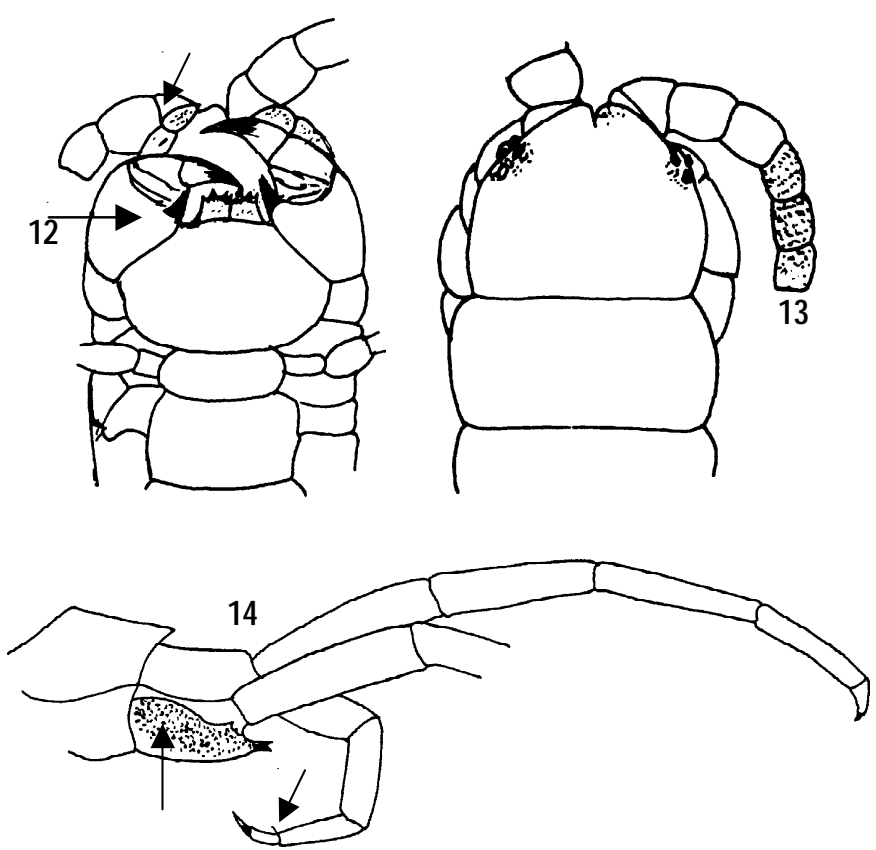

Figures 12-14. Rhysida nuda subnuda

12 - Cephalic end in ventral view showing maxillipedes and second maxillae; 13 - Cephalic end in dorsal view;

14 - caudal end in lateral view showing coxopleural process of anal leg and $20^{\text {th }}$ leg

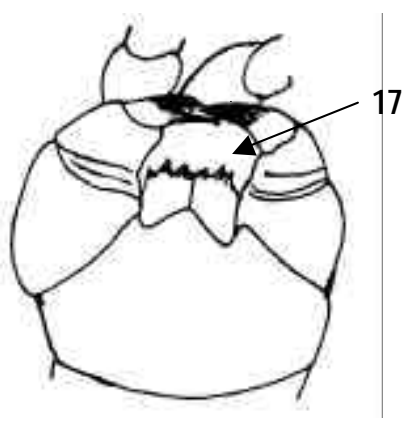

Figure 17. Ethmostigmus platycephalus platycephalus Cephalic end in ventral view showing maxillipedes

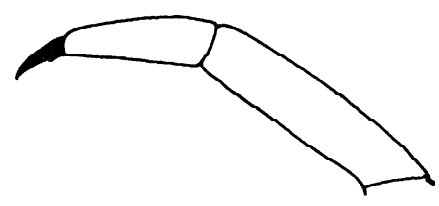

Figure 20. Digitipes indicus Distal part of anal leg 


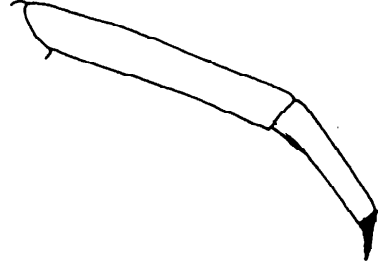

Figure 21. Digitipes chhotanii Distal part of anal leg

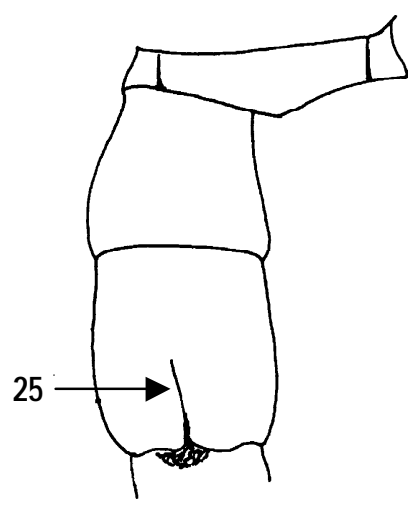

Figure 25. Asanada sukhensis

Caudal end in dorsal view showing $21^{\text {st }}$ tergite and proximal part of anal leg

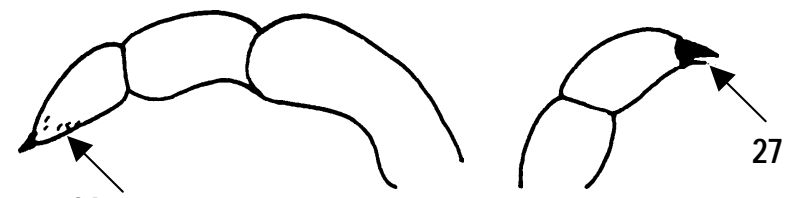

26

Figures 26-27. Distal end of $2^{\text {nd }}$ maxillae 26 - Digitipes gravelyi; 27 - Otostigmus sp.

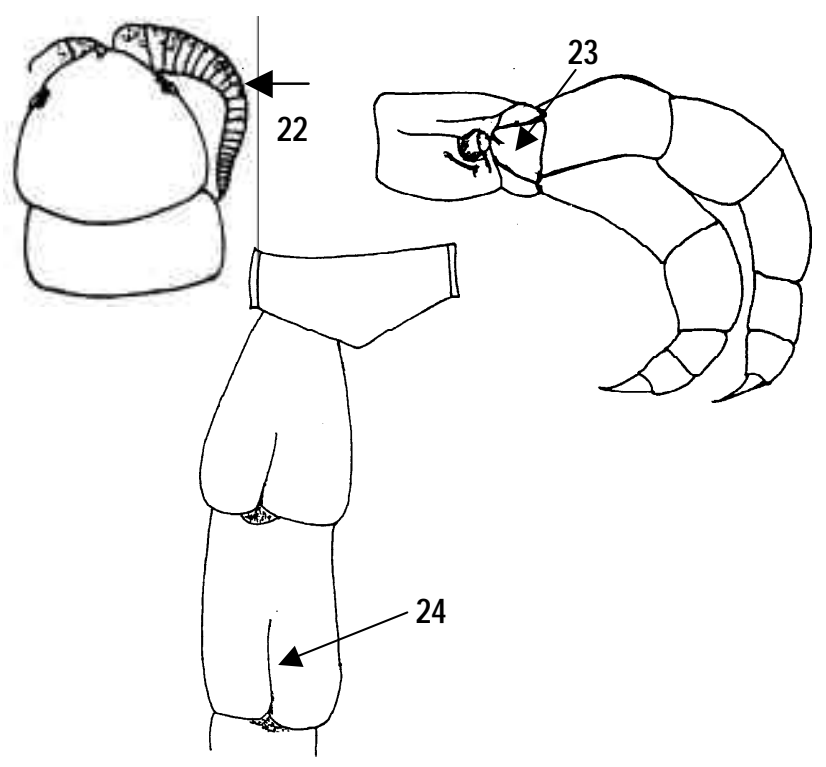

Figures 22-24. Asanada indica 22 - Cephalic end in dorsal view;

23 - caudal end in lateral view showing coxopleuron and anal legs; 24 - caudal end in dorsal view showing $21^{\text {st }}$ tergite and proximal part of anal leg 